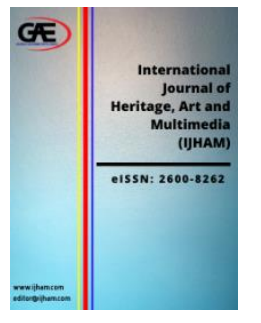

\author{
INTERNATIONAL JOURNAL OF \\ HERITAGE, ART AND MULTIMEDIA \\ (IJHAM) \\ www.ijham.com
}

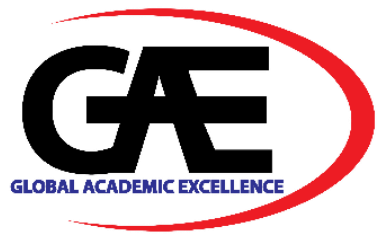

\title{
ROUTE DETERMINATION OF HISTORICAL ROADS BY LOCATION OF PREHISTORIC SETTLEMENTS: NORTH OF LAKE EBER
}

\author{
Ozdemir Kocak $^{1}$, Omur Esen ${ }^{2}$ \\ $1 \quad$ Lecturer Faculty, Selcuk University Türkiye (SÜ), Türkiye \\ Email: okocak@selcuk.edu.tr, orcid.org/0000-00032284-0441 \\ 2 Directorate of Construction-Technical Works, Selcuk University Türkiye (SÜ), Türkiye, \\ Email: omuresen@ selcuk.edu.tr, orcid.org/0000-0003-2775-6601
}

\section{Article Info:}

Article history:

Received date:31.12.2019

Revised date: 04.02. 2020

Accepted date: 06.06.2021

Published date: 15.06 .2021

\section{To cite this document:}

Kocak, O., \& Esen, O. (2021). Route Determination of Historical Roads by Location of Prehistoric Settlements: North of Lake Eber. International Journal of Heritage, Art and Multimedia, 4 (13), 11-20.

DOI: $10.35631 /$ IJHAM.413002.

This work is licensed under $\underline{\text { CC BY } 4.0}$ (c)

\begin{abstract}
:
Prehistoric settlements are prominent among the most important representatives of the cultural heritage in Turkey. These settlements are important for understanding the social, cultural, and economic conditions of the people who had lived in the past. As a matter of fact, these ancient settlements (mounds) and their locations to each other are taken as a basis in understanding the prehistoric routes. In this study, a route is identified beginning from the settlements in the north of a lake called Eber Gölü, which is located in the western part of Turkey. In this project, the study methods of Ancient History, Archaeology and Geodesy, and Photogrammetry Engineering are used. According to that, first old settlements are identified, threedimensional maps of these settlements are created and dating is carried on based on the ceramics (sherds) that are found on the settlements. All of this data is then overlapped. Successive settlements are observed in the east-west direction in the north of Lake Eber. These settlements reach a large mound called Üçhöyük in the westernmost part. In the east, it extends in different directions. Findings dating back to the 5th millennium BC (Chalcolithic Age) were found in these mounds. It is understood that the ceramics among these finds reflect a common tradition. This also supports the connection between these settlements. It is also possible to see some of these settlements from other settlements by the naked eye. Thus, it can be thought that the settlements in the north of the aforesaid lake have been in contact with each other since the prehistoric period. It can also be said that this relationship started in the Chalcolithic Age, continued during the Early Bronze Age, Middle Bronze Age, Iron Age, Hellenistic Period, and Roman Period, because it is determined that the findings (especially sherds) belonging to these periods are very similar.
\end{abstract}


Volume 4 Issue 13 (June 2021) PP. 11-20

DOI 10.35631/IJHAM.413002

Keywords:

Cultural Heritage, Mounds, Historical Natural Roads, Prehistoric Period

\section{Material And Method Of The Study}

Turkey is a country rich in antiquities and archaeological sites. However, this richness causes difficulties in the protection and evaluation of these works. We identified numerous examples during our research carried out in western Turkey on this issue. Most of these examples are mounds and cemeteries dating back to prehistoric times. Our study subject starts from the period of the first village settlements in Turkey (Neolithic) and reaches to the Late Iron Age. In other words, it is the period that is from about $9000 \mathrm{BC}$ to about $500 \mathrm{BC}$. However, the earliest settlement in this study belongs to around 5500 BC (Figure 1-3). We use the methods of Ancient History, Archaeology and Geodesy and Photogrammetry Engineering during our studies (MacDonagh 2005; Fovat-Zakšek 2014; Whitley-Hicks 2003). Our study is based on archaeological surveys in the region. Before we start these surveys, we determine a certain study route. Then from different maps (such as 1:25,000, 1: 5,000) we can identify the points or rises that may belong to the historical settlements on this route. This is a preliminary study. When we go to the field, the places I have marked on these maps are examined first. We can also identify places that we cannot see or notice on the map, either by asking the local people or by our own observations. During our surveys, the most important finds of the ancient people are the well known mounds around Anatolia / Mesopotamia. The mounds are the overlapping ruins of the historical settlements. In Anatolia and Mesopotamia, an area near fertile water resources is selected for settlement and settlements are built as one on the top of the other in the same area. Sometimes, such an area is inhabited for 30-40 different periods and throughout thousands of years. The archaeological remains on this mound are examined after the detection of such a mound during our archaeological surveys. The most common finds on the settlements are pottery pieces (sherds) that last for thousands of years because they are made of terracotta. It is sometimes possible to find thousands of sherds on a mound (Figure 7). In addition, pieces of tools made of stone and obsidian, weights of carpet-rug loom made of terracotta and stone, and figurines are important examples for our evaluation. We compare the fragments we have obtained with the archaeological excavations and the firm and exact-dated examples. Thus, in comparative chronology, we understand when the archaeological site was inhabited and when the cemetery was used where we are working on. Another important study at the archaeological site we found is the mapping (Figure 4). The geodesy and photogrammetry engineers in our team observe the boundaries of the site based on the information we provide. Then they map the archaeological site and its surroundings. Thus, the location of an ancient settlement and cemetery on the map system is clearly shown. The spread of the archaeological site on this map also occurs. Its width, height, location are accurately processed on the map. When these studies are carried out on a geographical area of a certain width, we get materials related to a few archaeological sites. We evaluate these archaeological sites first in themselves and then by comparing them with each other. Thus, which cultures and traditions exist in the prehistoric times, whether there is a political and commercial connection between these settlements begins to emerge. It is difficult to determine the roads used from prehistoric times to the Roman period which was a wide period. In this case, using the method described above, these routes are determined approximately. This method of study also facilitates the dating and identification of ancient settlements here. 
Volume 4 Issue 13 (June 2021) PP. 11-20

DOI 10.35631/IJHAM.413002

\section{Literature Review}

Our study was carried out in a major lake basin in Turkey. There is a lake called Eber Lake in this area. Due to the climatic conditions, this lake is now largely dry. We conducted research in an area in the east-west direction to the north of this lake. During our research, we identified five large settlements in this area: Ortakarabağ Çataltepe, Ortakarabağ Mezarlıktepe (Figure 45), Sinneli, Çataltepe (Karakaya) (Figure 6-7), Bozkuş Mound (Figure 1). Each of these settlements was on the natural road between the Emir Mountains Range in the north and Lake Eber in the south.

There have not been many studies about these periods near our study areas. J. Mellaart conducted surveys in this area in 1970s (Lloyd\&Mellaart 1965; Mellaart, 1974; Mellaart\&Murray, 1995). These studies are important in understanding the cultural development of the region from the Neolithic to the Iron Age. One of the archaeological excavations near this area is the Kusura Mound excavations conducted by W. Lamb in the district of Sand1kl1 in 1935-1936 (Lamb, 1936; Lamb, 1937; Gill 2018). These studies have yielded significant stratigraphic results regarding both the Inner-Western Anatolia Region and especially the Bronze Age cultures of Anatolia. The excavations carried out by K. Emre at the Yanarlar Cemetery in Bayat district (Emre, 1978) and our excavations at the Dede Mezar1 Cemetery in Bayat district together with the Afyonkarahisar Archaeology Museum (Koçak\&Üyümez\&Çay\&İlaslı\&İşçan, 2007; Üyümez\&Koçak\&İlaslı\&Çay\&İşçan, 2007) are important for understanding the Middle Bronze Age burial traditions in Anatolia. The large scaled studies in this region were carried out by us during 18 research seasons between the years of 2002 and 2019. During these studies, approximately 310 archaeological sites from $7000 \mathrm{BC}$ to Roman Period were investigated. A significant number of these sites were discovered by us for the first time. During our studies, cultural features, settlement characteristics and road connections of the region were emphasized, especially in the Neolithic, Chalcolithic, Bronze and Iron Age. Two books covering these topics (Koçak, 2004a; Koçak \& Bilgin \& Küçükbezci, 2019, see Bibliography) and 42 articles were conducted. The last of these books deals with the status of the region in the 2nd millennium $\mathrm{BC}$, which also includes the area mentioned in this article, which is called Inner-West Anatolia. For map studies, the studies conducted around Sligo, which has been used since the Neolithic Age (MacDonagh 2005), the example of Nimes in the south of France (Fovat-Zakšek 2014), and the studies around Piedmont in the east of America (Whitley-Hicks 2003) were taken as reference.

\section{Settlements In North Of Lake Eber And Road Route}

As mentioned above, there are five large mounds extending in the east-west direction to the north of Lake Eber: Ortakarabağ Çataltepe, Ortakarabağ Mezarlıktepe, Sinneli, Çataltepe (Karakaya), Bozkus Mound. There are two mounds on the west and northeast directions of these: Bolvadin Üçhöyük in the west, Büyük Karabağ Maltepesi in the northeast. Bolvadin Üçhöyük on the western of these settlements, and Mound of Büyükkarabağ Maltepesi on the northeast can also be counted here. We can give the dimensions of these settlements in two groups: 1-"Medium size settlements" with a diameter of approximately $300 \mathrm{~m}, 2$ - "Large settlements" over diameter of approximately $300 \mathrm{~m}$.

Three of the settlements we examined, including Üçhöyük and Büyükkarabağ Maltepesi Mound, were "medium-sized settlements", four of them can be considered as "large settlements" (Figure 3). The extensive finds of the Chalcolithic Age, Early Bronze Age, Middle 
Volume 4 Issue 13 (June 2021) PP. 11-20 DOI 10.35631/IJHAM.413002

Bronze Age and Iron Age finds in the settlements indicate that these were large villages or small towns of these periods. Of these, Bolvadin Üçhöyük and Derekarabağ Çataltepe are much larger than the others and they should probably be the most important settlements of the region in certain periods. The area where these mounds are located is bordered by the high Emir Mountains Range in the north and Lake Eber in the south (Figure 1, 3). Thus, a natural road route emerges between this mountain range and the lake. This road route should have been used as early as the Chalcolithic Age (around 5400 BC) (Figure 2). Because in three of the 5 mounds we have found, finds belonging to this period were obtained. Moreover, the presence of Chalcolithic finds in Üçhöyük, which is the western link of these settlements, and the Büyük Karabağ Maltepesi, which is connected to the northeast, strengthens our opinions. During the Early Bronze Age (3200-2000 BC), the number of settlements increased in a significant part of Anatolia. Finds in five settlements of our study area and in two other settlements are seen in this period (Figure 2-3). This is a sign that the road in this section was used strongly during the Early Bronze Age. The same thing can be said of the Middle Bronze Age (2000-1500 BC). However, since the second half of the 2nd millennium BC the Hittite Empire, which strengthened in the central parts of Turkey, starts to extend its impact area to the west. The Hittite attacks that started in the western part of Anatolia also affect our work area and the number of settlements in this region decreases (Figure 3). It is difficult to say clearly whether the road route in our study area was used during the Late Bronze Age (1500-1200 BC) due to the decrease in the number of settlements and unclear written documents of this period. This uncertainty lasts until the beginning of the Iron Age. Since the second quarter of the first millennium BC, the number of settlements around Lake Eber and in the Inner-Western Anatolia Department has started to increase again. This must be related to the Phrygs who have a wide political and cultural influence in Anatolia. Thus, the use of the historical natural road in our study area continued during the Iron Age and later in the Hellenistic and Roman periods (Figure 3).

\section{Evaluation}

Our studying method was the determination of the archaeological sites in the field, the collection and evaluation of the archaeological finds in these mounds, and the acquisition of maps of the identified sites.

Our study area is located in the eastern part of the basin which is named as the Inner-Western Anatolia Section. There emerges a natural corridor between the Emir Mountains in the north and Lake Eber in the north. To the best of our knowledge, settlements from the earliest Chalcolithic Age are seen on the fertile basin. These settlements survive until the Roman Period, except for some interruptions. It is seen that these settlements extend along a certain line on the east-west line. This line points to a historical natural road for us. One of the first and most important end points of this road in the west is Bolvadin Üçhöyük. Bolvadin Üçhöyük settlement is almost the largest settlement of the region and it is located on an important crossroad. The eastward part of the road route in this basin extends in several directions. The most prominent one, supported by archaeological material, extends towards the Büyük Karabağ Maltepesi Mound in the northeast. This part of the road then joins the roads leading to EmirdagKonya. Another connection is evident on the route to the east. This is the Sultandağ 1 connection, which is likely to be particularly important in the Iron Age. 
Volume 4 Issue 13 (June 2021) PP. 11-20 DOI 10.35631/IJHAM.413002

In this project, we collected data by following our studying method. As a result of this method we have applied, we have determined this east-west oriented road route in the north of Eber Lake. This method, which we have applied, is a method that can be used in other areas to determine the unknown road routes belonging to prehistoric periods and which do not have remains on the surface.

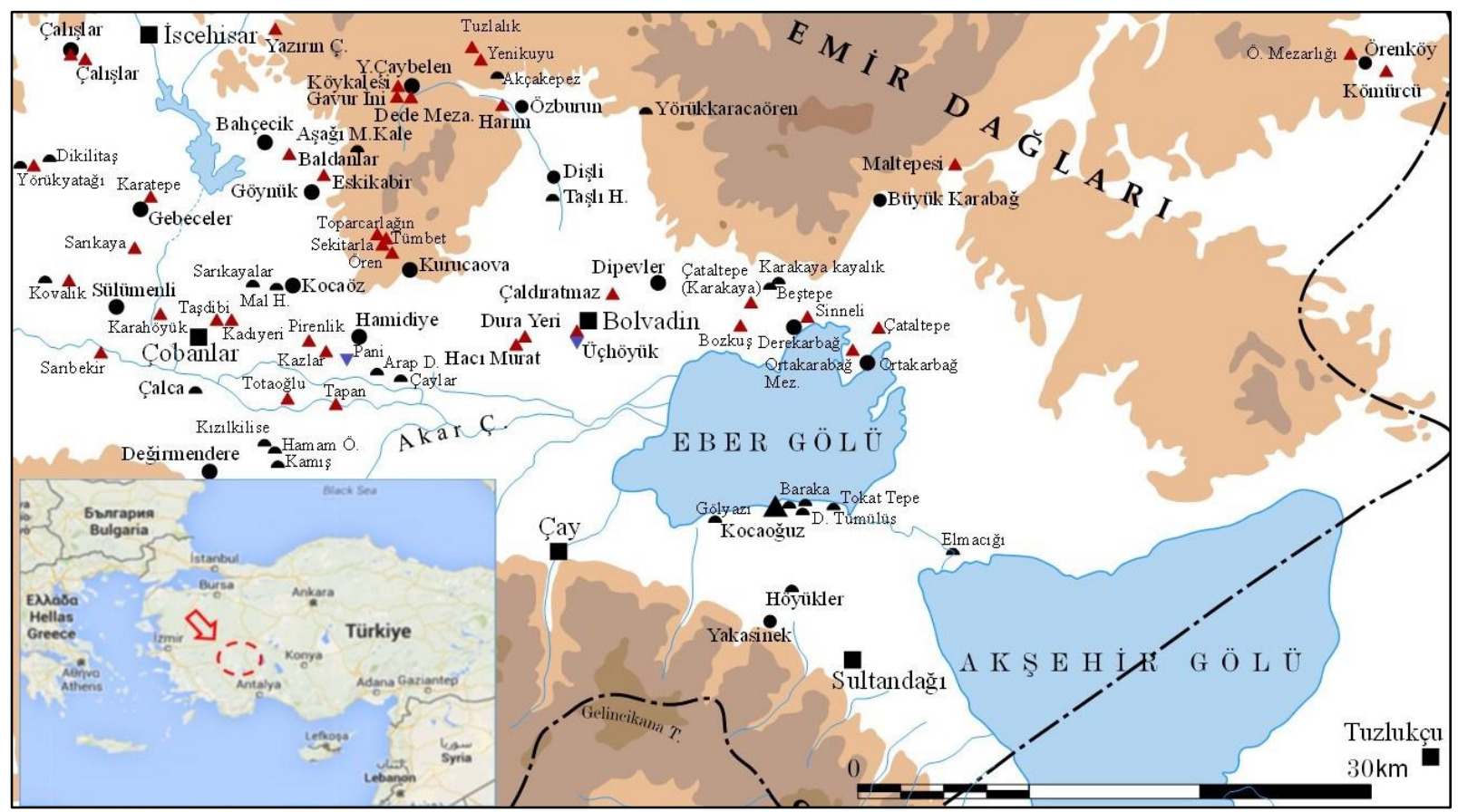

Figure 1: Study Area And Its Location In Turkey

\begin{tabular}{|c|c|c|c|c|c|c|c|}
\hline \multirow[b]{3}{*}{ 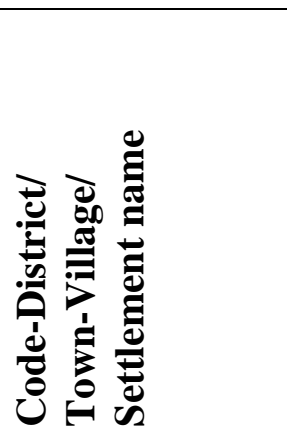 } & \multicolumn{7}{|c|}{ Periods } \\
\hline & \multirow[b]{2}{*}{ 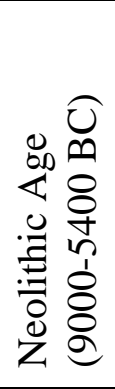 } & \multirow[b]{2}{*}{ 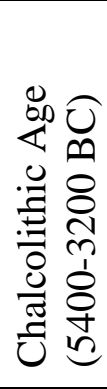 } & \multicolumn{3}{|c|}{$\begin{array}{l}\text { Bronze Age } \\
(3200-1200 \mathrm{BC})\end{array}$} & \multirow[b]{2}{*}{ 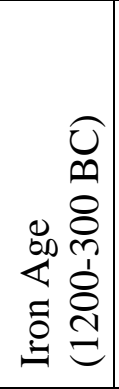 } & \multirow[b]{2}{*}{ 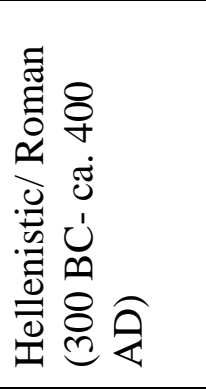 } \\
\hline & & & $\begin{array}{l}\text { EBA } \\
(320 \\
0- \\
2000 \\
\text { BC) }\end{array}$ & $\begin{array}{l}\text { MB } \\
\text { A } \\
(200 \\
0- \\
1500 \\
\text { BC) }\end{array}$ & $\begin{array}{l}\text { LBA } \\
(150 \\
0- \\
1200 \\
\text { BC) }\end{array}$ & & \\
\hline $\begin{array}{l}\text { 301.01-Bolvadin } \\
\text { Üçhöyüik }\end{array}$ & - & LCA & + & + & $+?$ & $+?$ & Hell/ Roma \\
\hline $\begin{array}{l}\text { 301.03-Bolvadin } \\
\text { Derekarabağ } \\
\text { Village } \\
\text { Sinneli Mound }\end{array}$ & - & + & + & + & - & + & Roma \\
\hline $\begin{array}{l}\text { 301.04-Bolvadin } \\
\text { B. Karabağ } \\
\text { Town } \\
\text { Maltepesi } \\
\text { Mound }\end{array}$ & - & LCA & + & + & - & - & Roma \\
\hline
\end{tabular}

Copyright $\odot$ GLOBAL ACADEMIC EXCELLENCE (M) SDN BHD - All rights reserved 


\begin{tabular}{|l|l|l|l|l|l|l|l|}
\hline $\begin{array}{l}301.05-B o l v a d i n \\
\text { Ortakarabağ } \\
\text { Village } \\
\text { Çataltepe Mound }\end{array}$ & - & - & + & + & - & + & Hell \\
\hline $\begin{array}{l}301.06-B o l v a d i n \\
\text { Derekarabağ } \\
\text { Village } \\
\text { Çataltepe/Karaka } \\
\text { ya }\end{array}$ & - & LCA & + & + & - & + & Hell/ Roma \\
\hline $\begin{array}{l}301.11-B o l v a d i n \\
\text { Ortakarabağ } \\
\text { Village } \\
\text { Mezarliktepe } \\
\text { Mound }\end{array}$ & - & + & + & + & - & + & Hell \\
\hline $\begin{array}{l}\text { 301.15-Bolvadin } \\
\text { Derekarabağ } \\
\text { Village } \\
\text { Bozkuş Mound }\end{array}$ & - & - & + & + & - & + & Roma \\
\hline
\end{tabular}

Figure 2: Settlements In The Study Area And Their Differentiation According To Their Periods (The Main Road Route That We Work Extends Towards Üçhöyük In The West (301.01) And Maltepesi Mound In The Northeast (301.04). In Our Study, We Mentioned About These Two Mounds)

\begin{tabular}{|c|c|c|c|c|c|c|}
\hline \multirow[b]{2}{*}{ 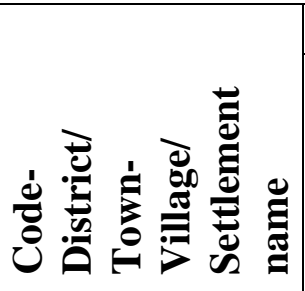 } & \multicolumn{3}{|l|}{ Direction } & \multirow[b]{2}{*}{ 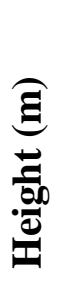 } & \multirow[b]{2}{*}{ 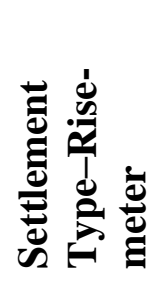 } & \multirow[b]{2}{*}{ 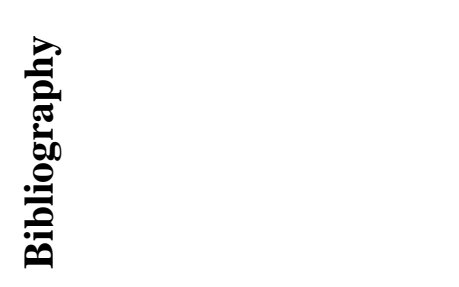 } \\
\hline & $\begin{array}{l}\text { Even } \\
\text { Direction }\end{array}$ & NS/EW & $\begin{array}{l}\text { NE-SW } \\
\text { /NW- } \\
\text { SE }\end{array}$ & & & \\
\hline $\begin{array}{l}\text { 301.01-Bolvadin } \\
\text { Üçhöyük }\end{array}$ & & $\begin{array}{l}650 \times 70 \\
0\end{array}$ & & 12 & $\begin{array}{l}\text { Mound } \\
\text { (996) }\end{array}$ & $\begin{array}{l}\text { Koçak, 2004a, 31-32; } \\
\text { Koçak, 2004b, 174; } \\
\text { Koçak, 2005, 21; } \\
\text { Koçak\&Bilgin, 2005, 91; } \\
\text { Koçak, 2013, 17-18; } \\
\text { Koçak, 2014, 81-84; } \\
\text { Koçak\&Bilgin\&Küçükbez } \\
\text { ci, 2016, } 11\end{array}$ \\
\hline $\begin{array}{l}\text { 301.03-Bolvadin } \\
\text { Derekarabağ } \\
\text { Village } \\
\text { Sinneli Mound }\end{array}$ & & $\begin{array}{l}200 \times 38 \\
0\end{array}$ & & 12 & $\begin{array}{l}\text { Mound } \\
(969)\end{array}$ & $\begin{array}{l}\text { Koçak, 2004a, 33; Koçak, } \\
\text { 2004b, } 175\end{array}$ \\
\hline $\begin{array}{l}\text { 301.04-Bolvadin } \\
\text { B. Karabağ } \\
\text { Town } \\
\text { Maltepesi } \\
\text { Mound }\end{array}$ & & $\begin{array}{l}300 \times 20 \\
0\end{array}$ & & 20 & $\begin{array}{l}\text { Mound } \\
\text { (1240) }\end{array}$ & $\begin{array}{l}\text { Koçak, 2004a, 34; Koçak, } \\
\text { 2004b, 175-176; Koçak, } \\
\text { 2005, 21; Koçak\&Bilgin, } \\
\text { 2005, } 91\end{array}$ \\
\hline
\end{tabular}


Volume 4 Issue 13 (June 2021) PP. 11-20 DOI 10.35631/IJHAM.413002

\begin{tabular}{|c|c|c|c|c|c|c|}
\hline $\begin{array}{l}\text { 301.05-Bolvadin } \\
\text { Ortakarabağ } \\
\text { Village } \\
\text { Çataltepe Mound }\end{array}$ & & $-/ 400$ & $-/ 580$ & 10 & $\begin{array}{l}\text { Mound } \\
(970)\end{array}$ & $\begin{array}{l}\text { Koçak, 2004a, 33-34; } \\
\text { Koçak, 2004b, 175 }\end{array}$ \\
\hline $\begin{array}{l}\text { 301.06-Bolvadin } \\
\text { Derekarabağ } \\
\text { Village } \\
\text { Çataltepe/Karaka } \\
\text { ya }\end{array}$ & & $\begin{array}{l}700 \times 45 \\
0\end{array}$ & & 12 & $\begin{array}{l}\text { Mound } \\
(970)\end{array}$ & $\begin{array}{l}\text { Koçak, 2004a, 33; Koçak, } \\
\text { 2004b, 175; Koçak, 2005, } \\
\text { 21; Koçak\&Bilgin, 2005, } \\
91\end{array}$ \\
\hline $\begin{array}{l}\text { 301.11-Bolvadin } \\
\text { Ortakarabă } \\
\text { Village } \\
\text { Mezarlıktepe } \\
\text { Mound } \\
\end{array}$ & & & $\begin{array}{l}300 \times 40 \\
0\end{array}$ & 10 & $\begin{array}{l}\text { Mound } \\
(968)\end{array}$ & Koçak, 2005, 20 \\
\hline $\begin{array}{l}\text { 301.15-Bolvadin } \\
\text { Derekarabağ } \\
\text { Village } \\
\text { Bozkuş Mound }\end{array}$ & $300 \times 300$ & & & 8 & $\begin{array}{l}\text { Mound } \\
(984)\end{array}$ & $\begin{array}{l}\text { Koçak, 2004a, 40; Koçak, } \\
\text { 2005, } 20\end{array}$ \\
\hline
\end{tabular}

Figure 3: The Dimensions And Heights Of The Settlements In The Study Area And Bibliography About This Subject

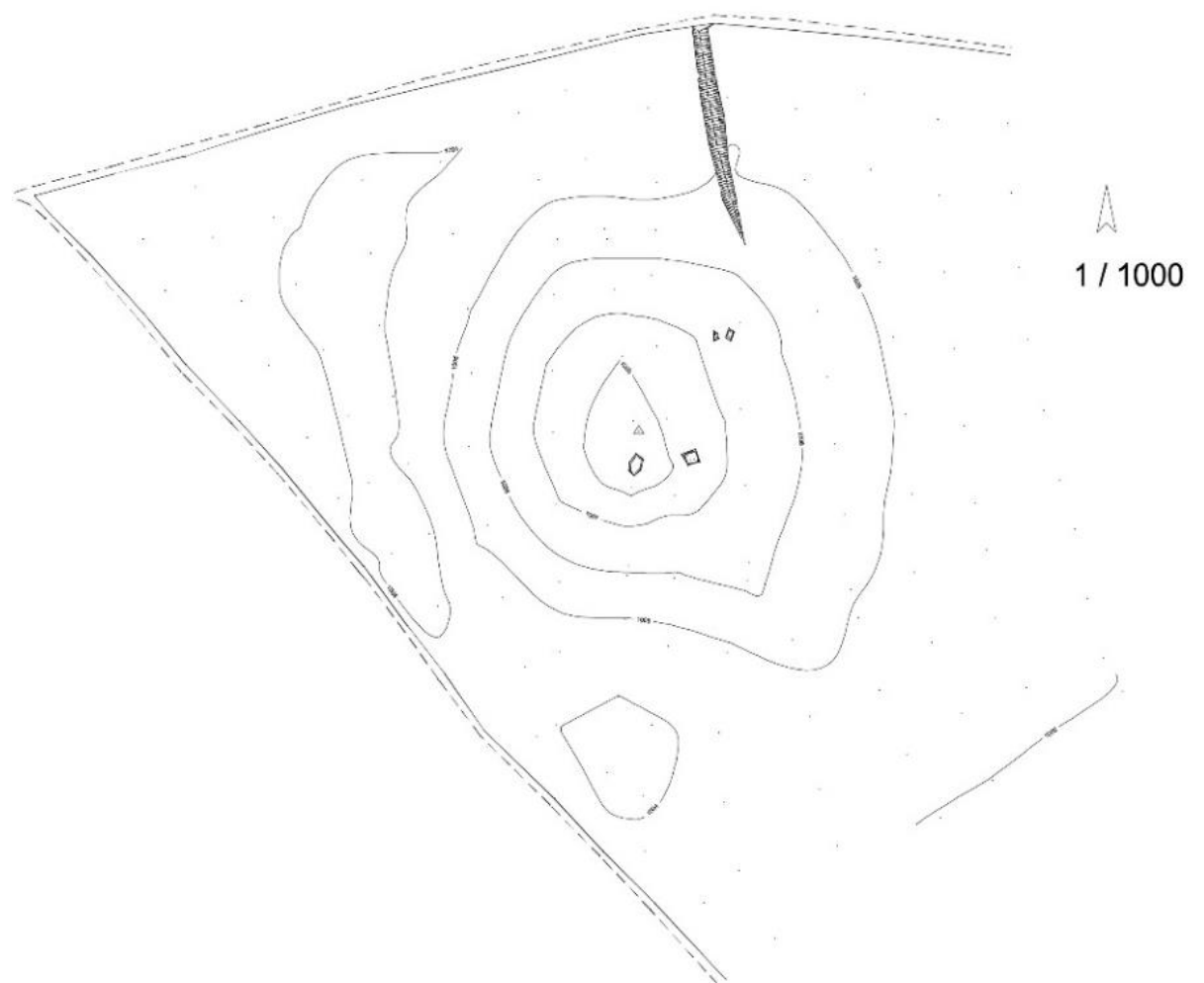

Figure 4: Plan of Ortakarabağ Mezarlıktepe Mound 

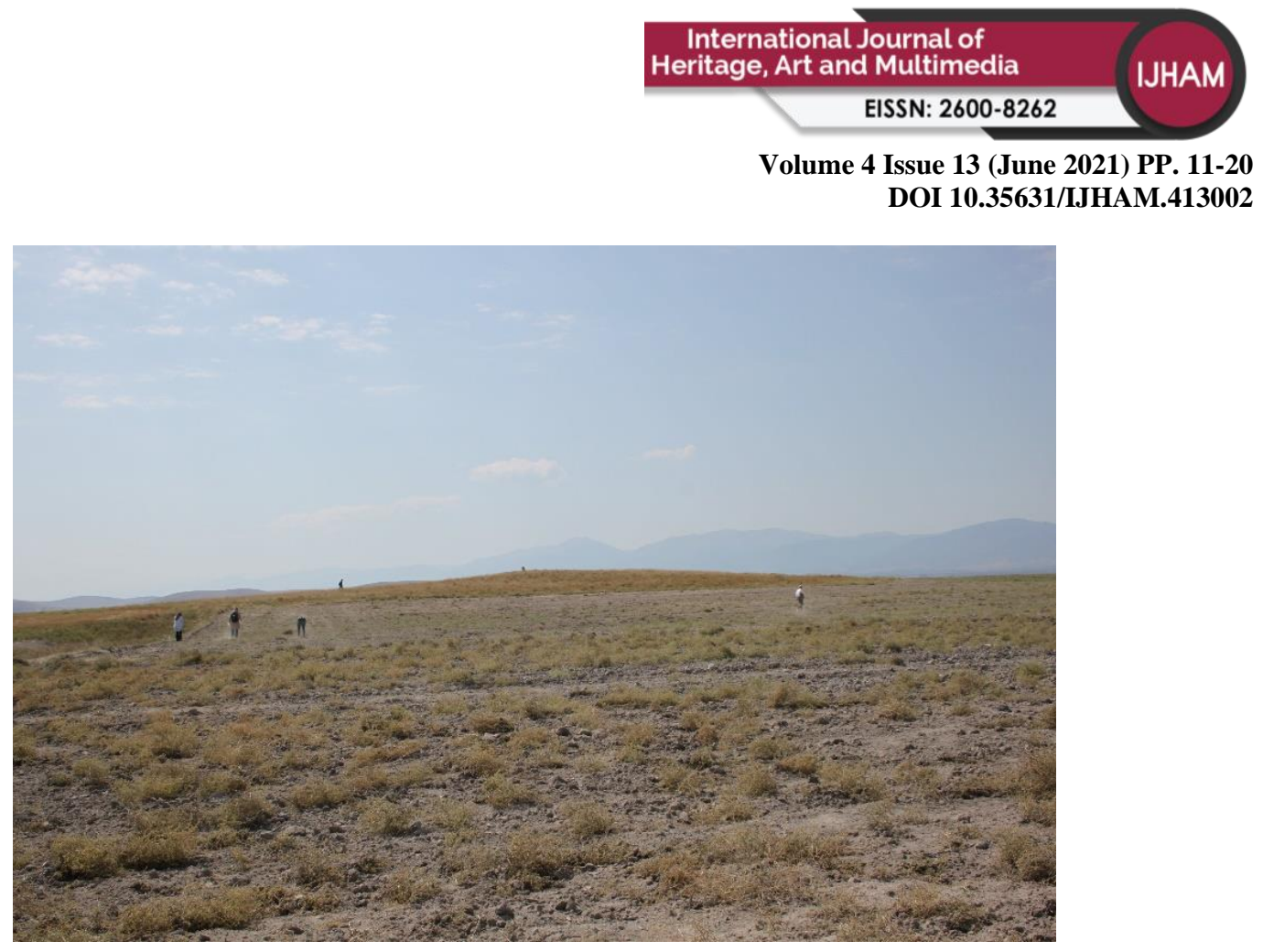

Figure 5: Ortakarabağ Mezarlıktepe Mound

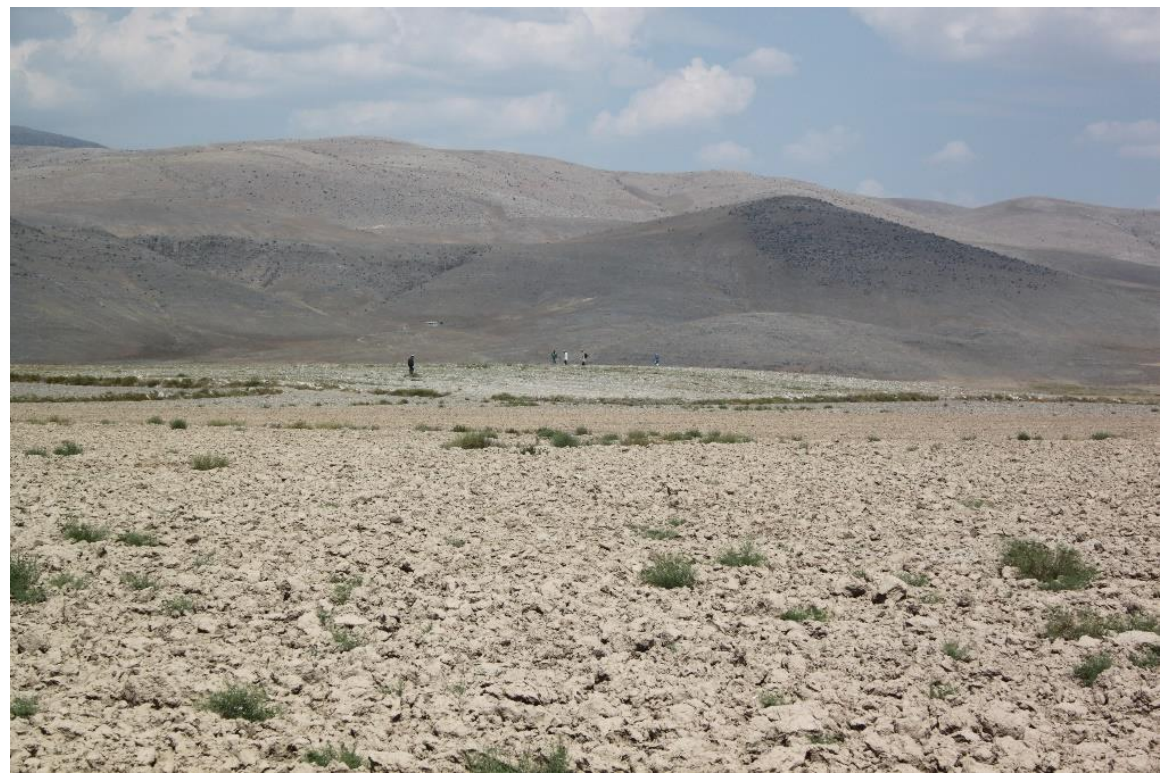

Figure 6: Derekarabağ Çataltepe Mound (Karakaya) 


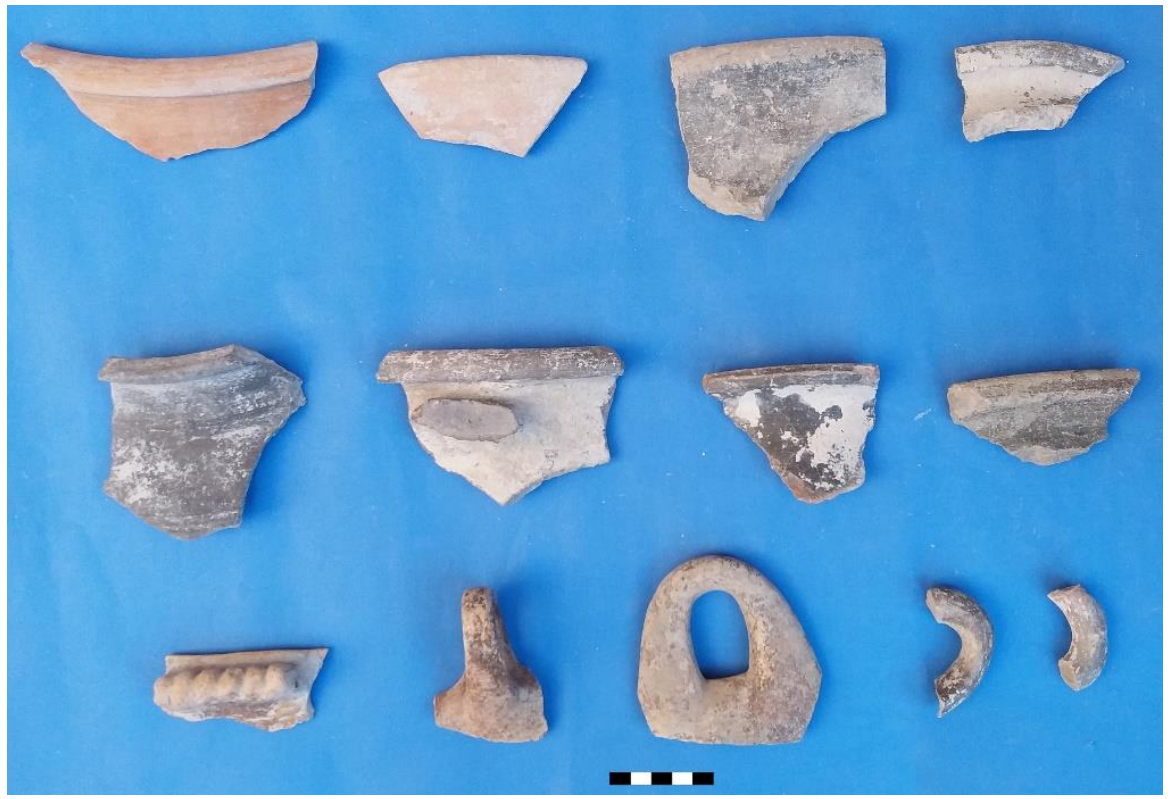

Figure 7: Sherds of Derekarabağ Çataltepe- Karakaya Mound

\section{Acknowledgement}

This project was supported by Turkish Historical Society and Selcuk University the Coordinatorship of Scientific Research Projects. We appreciate their valuable contribution: "2019 Archaeological Surveys and Mapping Studies in Afyonkarahisar and Its Districts Afyonkarahisar İli ve İlçeleri 2019 Yılı Yüzey Araştırmaları ve Harita Çalışmaları" (19401082 Project number); "Route Determination of Historical Roads by Location of Prehistoric Settlements: North of Lake Eber" (19701341 Project number).

\section{Bibliography}

Emre, K. (1978). Yanarlar. Afyon Yöresinde Bir Hitit Mezarlığı, Ankara.

Fovat, É., Zakšek, K. (2014), "Path Network Modelling and Network of Aggregated Settlements: A Case Study in Languedoc (Southeastern France)", Computational Approaches to the Study of Movement in Archaeology. Theory, Practice and Interpretation of Factors and Effects of Long Term Landscape Formation and Transformation, ed. S. Polla-P. Verhagen, Berlin, Boston, https://doi.org/10.1515/9783110288384, ISBN: 9783110288315, 43-71.

Gill, D. W. J (2018), Winifred Lamb. Aegean Prehistorian and Museum Curator, ISBN: 9781784918804.

Koçak, Ö. (2004a). Erken Dönemlerde Afyonkarahisar Yerleşmeleri, Kömen Yayınevi, Konya.

Koçak, Ö. (2004b). “Afyon-Bolvadin Yüzey Araştırmaları 2002 (Neolitik Çağ’dan İlk Tunç Çağına Kadar)”, Araştırma Sonuçları Toplantısı, XXI/1, Ankara,173-184.

Koçak, Ö. (2005). "Bolvadin, Çay ve Sultandağı Yüzey Araştırmaları 2003”, Araştırma Sonuçları Toplantısı, XXII-2, Ankara, 19-28. 
Volume 4 Issue 13 (June 2021) PP. 11-20

DOI 10.35631/IJHAM.413002

Koçak, Ö. (2013). "The Second Millennium B.C. Settlements and Cemeteries in the Eastern Interior of Mid-West Anatolia", L'Anatolie des Peuples, des Cités et des Cultures (II ${ }^{\mathrm{e}}$ Millénaire av. J.-C.- $\mathrm{V}^{\mathrm{e}}$ siècle ap. J.-C.) Colloque International de Besançon 26-27 Novembre 2010, Volume 2. Approches Locales et Régionales, édité par: Hadrien BruGuy Labarre, 15-29.

Koçak, Ö. (2014). “Afyonkarahisar İli ve İlçeleri 2012 Yı1ı Yüzey Araştırmaları”, Araştırma Sonuçları Toplantısı, XXXI/2, Ankara, 75-96.

Koçak, Ö., Bilgin, M. (2005). “Taşlı Höyük: An Important Early Bronze Age Settlement and Necropolis in Bolvadin-Dişli Village", Anatolia Antiqua, XIII, 85-109.

Koçak, Ö., Üyümez, M., Çay, T., İlaslı, A., İşcan, F. (2007), “An Important Middle Bronze Age Cemetery at West-Central Anatolia: Dede Mezari”, CIPA XXI International Symposium, Athens, XXI (poster).

Koçak, Ö., Bilgin, M., Küçükbezci, H. G. (2016). "The Determination of the Settlement Density in West of Turkey, between 6000-1200 B.C., According to Archaeological Findings", International Journal of Social Sciences, 3rd Asian Conference on Multidisciplinary Research in Higher Education (ACMRHE 2015), Manila, Philippines, 1-13.

Koçak, Ö., Bilgin, M., Küçükbezci, H. (2019). MÖ II. Binyılda Afyonkarahisar ve Çevresi Kültürleri, Türk Tarih Kurumu Yayınları, Ankara.

Lamb, W. (1936). "Excavations at Kusura near Afyon Karahisar”, Archaeologia, LXXXVI, 164, pl. 1-8.

Lamb, W. (1937). "Excavations at Kusura near Afyon Karahisar", Archaeologia, LXXXVII, 217-273, pl. 78-84.

Lloyd, S., Mellaart, J. (1965). Beycesultan, Vol.II, Middle Bronze Age Architecture and Pottery, Londra.

MacDonagh, M (2005), "Valley Bottom and Hilltop: 6.000 Years of Settlement along the Route of the N4 Sligo Inner Relief Road", Recent Archaeological Discoveries on National Road Schemes 2004 (Archaeology and the National Roads Authority Monographs), ISBN 0-9545955-1-3, Dundalk, 9-23.

Mellaart, J. (1974). "Western Anatolia, Beycesultan and the Hittites", Mansel'e Armağan I, 493-526.

Mellaart, J., Murray, A. (1995), Beycesultan, VOL. III, Part II, Ankara.

Üyümez, M., Koçak, Ö., İlaslı, A., Çay, T., İşcan, F. (2007), “Afyonkarahisar'ın Doğusunda Önemli Bir Tunç Çağı Nekropolü: Dede Mezarı”, Belleten, LXXI/262, Ankara, 811841, Harita, Çizim 1-19, Resim 1-32.

Whitley, T. G., Hicks, L. M. (2003), “A Geographic Information Systems Approach to Understanding Potential Prehistoric and Historic Travel Corridors", Southern Archaeology, Summer 2003, Vol. 22, No. 1, 77-91. 